East Tennessee State University

Digital Commons @ East Tennessee State University

\title{
Stability of Ampicillin in Normal Saline Following Refrigerated Storage and 24-hour Pump Recirculation
}

\author{
Mariah A. Huskey \\ East Tennessee State University \\ Paul O. Lewis \\ Ballad Health \\ Stacy D. Brown \\ East Tennessee State University
}

Follow this and additional works at: https://dc.etsu.edu/asrf

Huskey, Mariah A.; Lewis, Paul O.; and Brown, Stacy D., "Stability of Ampicillin in Normal Saline Following Refrigerated Storage and 24-hour Pump Recirculation" (2020). Appalachian Student Research Forum. 8. https://dc.etsu.edu/asrf/2020/presentations/8

This Oral Competitive is brought to you for free and open access by the Events at Digital Commons @ East Tennessee State University. It has been accepted for inclusion in Appalachian Student Research Forum by an authorized administrator of Digital Commons @ East Tennessee State University. For more information, please contact digilib@etsu.edu. 
Stability of ampicillin in normal saline following refrigerated storage and 24-hour pump recirculation

Mariah Huskey, BS, PharmD Candidate huskeym@etsu.edu

PURPOSE

- Use of ampicillin in outpatient parenteral antimicrobial therapy (OPAT) has historically been complicated by frequent dosing and short beyond use dates. This study investigates the possibility of preparing ampicillin in norma saline for continuous infusion and storing it prior to use METHODS

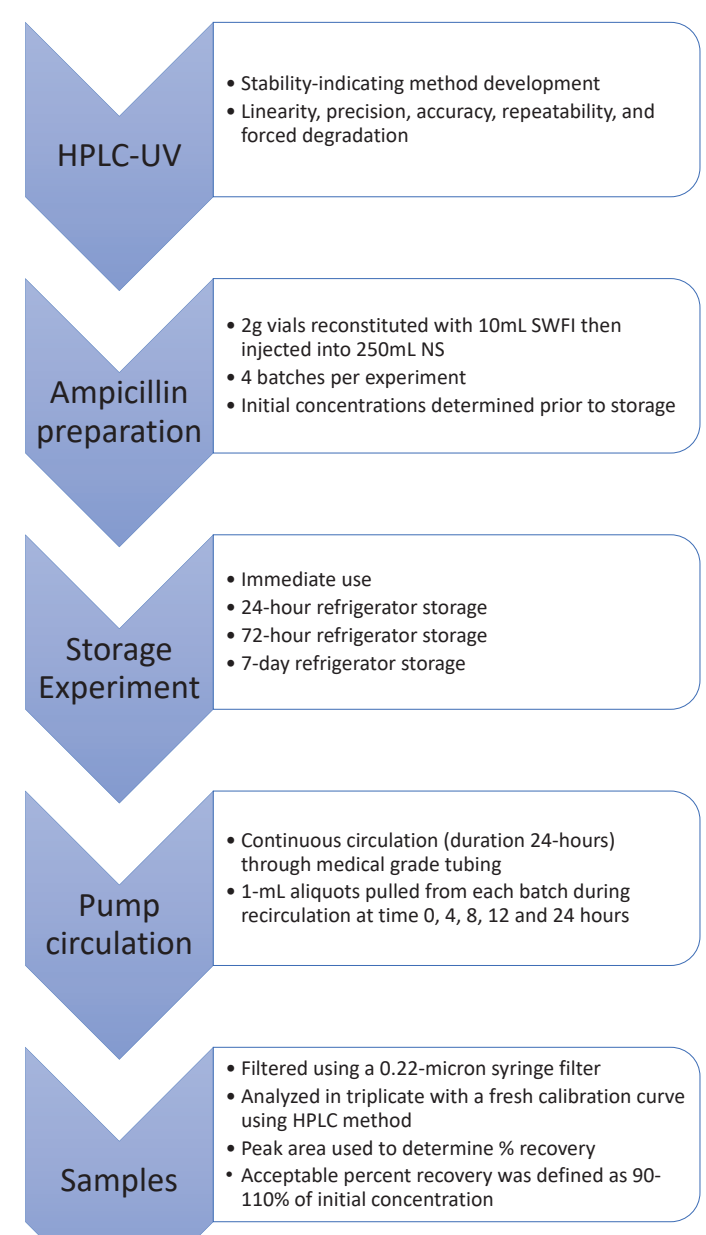

\section{Ampicillin can be prepared and stored} in a refrigerator for up to 72-hours prior to continuously infusing at room temperature over 24-hours with less than a $10 \%$ loss of potency.

\section{RESULTS}

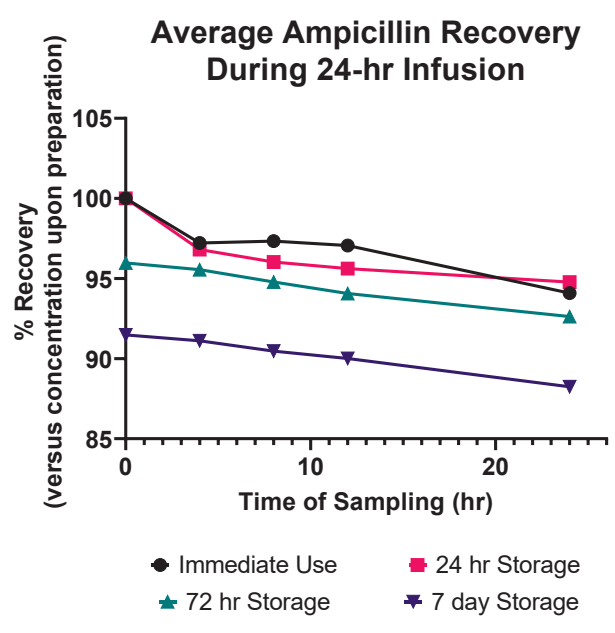

95\% Confidence Intervals for Ampicillin

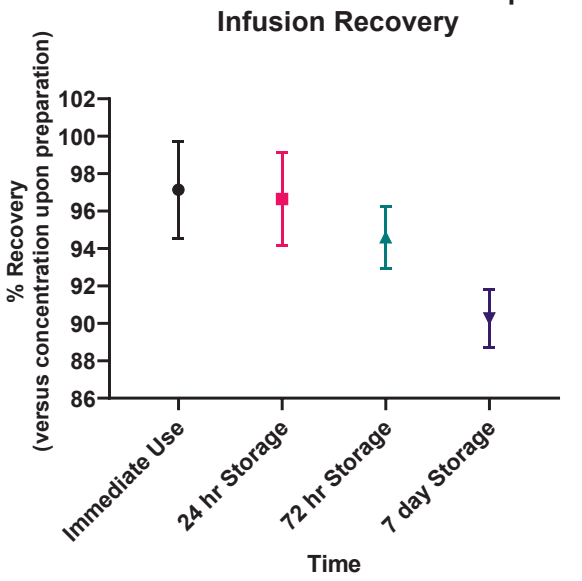

- Percent recovery remained above $90 \%$ for all batches and time points except for the 7-day storage experiment after 4 hours of circulation through the medical grade tubing

Mariah Huskey BS, PharmD Candidate', Paul Lewis PharmD, BCPD (AQ-ID)2, Stacy Brown PhD 1

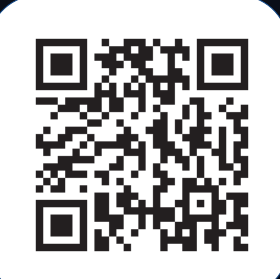

Take a picture to learn more about our research group
BILL GATTON

COLLEGE of PHARMACY EAST TENNESSEE STATE UNIVERSITY

BalladHealth

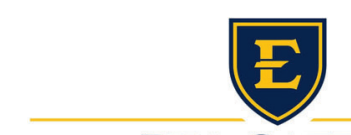

